\title{
PERLINDUNGAN PRODUK-PRODUK BERPOTENSI HAK KEKAYAAN INTELEKTUAL MELALUI INDIKASI GEOGRAFIS
}

\author{
Lily Karuna Dewi* \\ Putu Tuni Cakabawa Landra** \\ Program Kekhususan Hukum Bisnis Fakultas Hukum Universitas \\ Udayana
}

\begin{abstract}
ABSTRAK
Indonesia sebagai negara yang menyimpan berbagai kekayaan alam tentunya memiliki banyak potensi Indikasi Geografis untuk selalu dikembangkan Perlindungan bagi Indikasi Geografis merupakan hal yang harus dipandang serius karena merupakan hasil dari karya intelektual untuk menghindari pelanggaran atau penyalahgunaan hak-hak yang timbul dari lahirnya karya intelektual tersebut. Tujuan penulisan ini yaitu untuk mengkaji dan memahami kriteria yang wajib dipenuhi agar suatu produk dapat didaftarkan sebagai Indikasi Geografis serta mekanisme pendaftaran suatu produk yang berpotensi sebagai Indikasi Geografis. Penulisan ini menggunakan jenis metode penelitian hukum normatif dengan menggunakan jenis pendekatan perundang-undangan dan pendekatan analisis konsep hukum. Berdasarkan hasil analisa, agar suatu produk dapat dikatakan berpotensi sebagai produk Indikasi Geografis maka haruslah memenuhi syarat objektif dan syarat subjektif. Mekanisme pendaftaran suatu produk yang berpotensi sebagai Indikasi Geografis yaitu diawali dengan pengajuan permohonan kepada Direktorat Jendral Kekayaan Intelektual, lalu Tim Ahli Indikasi Geografis melakukan pemeriksaan substantif, setelah itu diterbitkannya sertifikat Indikasi Geografis oleh Direktorat Jendral Hak Kekayaan Intelektual. Dengan terbitnya Sertifikat Geografis ini maka suatu produk tersebut resmi dilindungi dan dimiliki secara kolektif oleh masyarakat penghasil barang Indikasi Geografis.
\end{abstract}

\section{Kata Kunci: Indikasi Geografis, Pendaftaran, Kriteria}

*Lily Karuna Dewi adalah Mahasiswa Fakultas Hukum Universitas Udayana, Korespondensi : lilykaruna@yahoo.com.

${ }^{* *}$ Putu Tuni Cakabawa Landra adalah Dosen Fakultas Hukum Universitas Udayana. 


\begin{abstract}
Indonesia as a country that has various natural assets certainly has many potential Geographical Indication to always be developed, protection for Geographical Indication is something that must be taken seriously because it is the result of intellectual work to avaoid violations or misuse of rights arising from the birth of that intellectual work. The aim of this writing is to understand and related criteria that must be fulfilled so that a product can be registered as a Geographical Indication and the mechanism for registering a product that has the potential as a Geographical Indication. This writing used a type of normative legal research method by using the types of the statute approach and legal concept analysis approach. The results of the analysis are, based on the results of the analysis so that a product can be said to have the potential as a product of Geographical Indication, it must meet the objective requirements and subjective requirements. The registration mechanism of a product that has the potential as a geographical indication is initiated by submitting a request to the Directorate General of Intellectual Property Rights, then the Geographical Indication Expert Team conducts a substantive examination, after which the Geographical Indication certificate is issued by the Directorate General of Intellectual Property Rights. With the issuance of this Geographic Certificate, a product is officially protected and owned collectively by the community that produces Geographical Indications.
\end{abstract}

\title{
Key Words: Geographical Indication, Registration, Criteria
}

\section{PENDAHULUAN}

\section{$1.1 \quad$ Latar Belakang}

Kekayaan Intelektual (KI) merupakan sesuatu yang dihasilkan dari daya pikir seseorang, diekspresikan lalu dituangkan menjadi produk berupa teknologi, ilmu pengetahuan, sastra dan seni budaya yang mana semuanya itu terlahir dengan perjuangan. Indonesia menyimpan begitu banyak kekayaan alam dengan keunikannya masing-masing yang bercirikan daerah asalnya. Maka tak heran terdapat begitu banyak produk-produk Indikasi Geografis dari setiap 
daerahnya. Indikasi Geografis merupakan tanda atau ekspresi yang mencerminkan daerah asal suatu barang yang karena faktor lingkungan geografis meliputi faktor alam, faktor manusia atau kombinasi dari kedua faktor tersebut yang selanjutnya memberikan kekhasan karakteristik, ciri serta kualitas tertentu pada suatu produk tertentu. ${ }^{1}$

Dilihat dari sejarah hukum, awal mula pengaturan Indikasi Geografis yaitu tertuang pada pasal 56 ayat (1) Undang-Undang Nomor 15 Tahun 2001 tentang Merek lalu selanjutnya terbit peraturan pelaksananya yaitu pada Peraturan Pemerintah Nomor 51 Tahun 2007 tentang Indikasi Geografis dan sampai dengan pengaturan terbaru pada Undang-Undang Nomor 20 Tahun 2016 tentang Merek dan Indikasi. Selain itu, Indikasi Geografis juga memiliki pengaturan khusus oleh Direktorat Jenderal Kekayaan Intelektual dan juga diakui oleh Kementrian Hukum dan Hak Asasi Manusia yang dituangkan dan diterbitkan pada Buku Indikasi Geografis Indonesia. Indonesia memiliki banyak sekali potensi Indikasi Geografis yang perlu segera didaftarkan ke kantor Direktorat Jendral Kekayaan Intelektual Indonesia. ${ }^{2}$ Perlindungan Indikasi Geografis yang merupakan bagian dari Kekayaan Intelektual semenjak penandatanganan Persetujuan TRIP's (yang selanjutnya disebut TRIPS) di tahun 1994 haruslah dipandang sangat penting agar suatu Indikasi Geografis bisa benar-benar memberikan

${ }^{1}$ I Ketut Haris Wiranata dan Anak Agung Sri Indrawati, 2014, Pendaftaran Kembali Hak Merek Dagang Indikasi Geografis, Jurnal Kertha Semaya, Fakultas Hukum Universitas Udayana, Vol. II, No. 5, h. 2, URL: https://ojs.unud.ac.id/index.php/kerthasemaya/article/view/10357, diakses pada tanggal 19 Februari 2019 pukul 16:35.

2 Abdul Atzar, 2018, Mengenal Lebih Dekat Hukum Hak Kekayaan Intelektual, Penerbit Deepublish, Yogyakarta, h. 74. 
keuntungan bagi masyarakat dan atau perwakilan masyarakat yang merupakan suatu komunitas yang berhak dari daerah tersebut. ${ }^{3}$

Suatu produk Indikasi Geografis harus didaftarkan agar mendapatkan perlindungan. Namun sebelum didaftarkan, produk yang berpotensi sebagai Kekayaan Intelektual tersebut haruslah memenuhi kriteria. Dalam pasal 56 ayat (1) Undang-Undang Merek dan Indikasi Geografis mengatur tentang Permohonan Indikasi Geografis yang tidak dapat didaftarkan, pada huruf b pasal ini menyebutkan "menyesatkan atau memperdaya masyarakat mengenai reputasi, kualitas, karakteristik, asal sumber, proses pembuatan barang, dan/atau kegunaannya." Namun tidak dijelaskan lebih lanjut mengenai apa yang menjadi kualifikasi sehingga dapat dikatakan "menyesatkan masyarakat". Dalam bagian penjelasan pasal pun hanya menyebutkan bahwa ketentuan pasal ini cukup jelas, sehingga hal ini menimbulkan norma kabur pada pengaturan ketentuan tersebut. Maka perlu diketahui sebenarnya kriteria apa saja yang wajib terpenuhi oleh suatu produk dapat didaftarkan sebagai suatu Indikasi Geografis.

\subsection{Permasalahan}

Berdasarkan penjabaran latar belakang diatas, terdapat dua rumusan masalah yaitu :

1. Apa saja kriteria yang wajib dipenuhi agar suatu produk dapat didaftarkan sebagai Indikasi Geografis?

2. Bagaimana mekanisme pendaftaran suatu produk yang berpotensi sebagai Indikasi Geografis?

${ }^{3}$ Ibid, h. 63. 


\subsection{Tujuan Penulisan}

Penulisan ini bertujuan untuk mengkaji dan menganalis kriteria yang wajib dipenuhi suatu produk agar dapat didaftarkan sebagai Indikasi Geografis serta mekanisme pendaftaran suatu produk yang berpotensi sebagai Indikasi Geografis.

\section{ISI MAKALAH}

\subsection{Metode Penelitian}

Jenis penelitian dalam penulisan jurnal hukum ini yaitu penelitan hukum normatif yang sumber datanya berasal dari bahan hukum primer dan sekunder. ${ }^{4}$ Jenis pendekatan yang digunakan yaitu pendekatan perundang-undangan dan pendekatan analisis konsep hukum dengan sumber data dari bahan hukum primer yang berupa perundang-udangan sehubungan dengan Indikasi Geografis antara lain Undang-Undang Nomor 20 Tahun 2016 tentang Merek dan Indikasi Geografis serta Peraturan Pemerintah Nomor 51 Tahun 2007 tentang Indikasi Geografis dan bahan hukum sekunder yang terdiri dari buku-buku, jurnal, dan literatur lain yang berkaitan dengan topik pembahasan.

\subsection{Hasil dan Pembahasan}

\subsubsection{Kriteria yang Wajib Dipenuhi Agar Suatu Produk Dapat Didaftarkan Sebagai Indikasi Geografis}

Masih banyak masyarakat yang kurang mengerti arti penting dari perlindungan Indikasi Geografis di Indonesia bahkan perhatian pemerintah kepada Indikasi Geografis pun tidak sebesar kepada

4 Amiruddin, Zainal Asikin, 2016, Pengantar Metode Penelitian Hukum, Jakarta, RajaGrafindo Persada, h. 118-119. 
bidang Kekayaan Intelektual seperti paten dan merek. ${ }^{5}$ Eksistensi TRIPs sangat memiliki peran dalam melindungi Indikasi Geografins khususnya bagi negara Indonesia. Namun sebelum TRIPs, Indikasi Geografis pun sudah diakui dalam beberapa konvensi ataupun treaty. ${ }^{6}$ Indonesia lantas meng-harmonisasikan TRIPS's kedalam hukum positif dimulai dari tahun 2000 pemerintah telah mengundangkan beberapa Undang-Undang baru di bidang Kekayaan Intelektual, salah satunya adalah UU Merek dan Indikasi Geografis yang merupakan Undang-Undang terbaru tentang Kekayaan Intelektual. ${ }^{7}$

Bila merujuk pada pengertian Indikasi Geografis yang terdapat dalam ketentuan Pasal 1 angka (6) UU Merek dan Indikasi Geografis, maka dapat dikatakan bahwa sesuatu karya bila ingin mendapat perlindungan Kekayaan Intelektual dalam bidang Indikasi Geografis haruslah dilekatkan pada suatu barang. Dengan kata lain, harus ada "produk barang" yang dihasilkan dari suatu wilayah geografis tertentu yang memiliki ciri dan kekhasan tertentu yang berbeda dengan geografis lainnya. ${ }^{8}$ Selain tanda pembeda, aspek-aspek khusus dari nama asal barang juga harus memiliki nilai ekonomis. Artinya bahwa nama asal itu tidak hanya berfungsi sebagai pembeda antara barang satu dan lainnya, tetapi juga harus jelas bahwa tempat asal ini memiliki pengaruh yang besar terhadap peningkatan kualitas

5 Winda Risna Yesiningrum, 2015, Perlindungan Hukum Indikasi Geografis Sebagai Bagian Dari Hak Kekayaan Intelektual, Jurnal IUS, Vol. 3, No. 7, h. 42, URL: $\quad$ http://jurnalius.ac.id/ojs/index.php/jurnalIUS/article/view/198 diakses pada tanggal 4 Februari 2019 pukul 22:17.

6 Djulaeka, 2014, Konsep Perlindungan Hak Kekayaan Intelektual Perspektif Kajian Filosofis HaKi Kolektif-Komunal, Setara Press, Malang, h. 3.

7 Ni Ketut Supasti Dharmawan, dkk, 2018, Harmonisasi Hukum Kekayaan Intelektual Indonesia, Swasta Nulus, Denpasar, h. 52.

8 Ibid, h. 68. 
atau mutu barang tersebut, sehingga nantinya akan meningkatkan harga jual produk tersebut. ${ }^{9}$

Agar suatu produk dapat dikatakan berpotensi sebagai produk Indikasi Geografis maka haruslah memenuhi syarat objektif dan syarat subjektif. Syarat subjektif digunakan sebagai tolak ukur apakah suatu produk dapat dikatakan berhasil dan layak sebagai produk Indikasi Geografis atau tidak. Syarat keberhasilan tersebut diatur oleh Direktorat Jenderal Kekayaan Intelektual yang dituang di dalam Buku Indikasi Geografis Indonesia. Adapun syarat tersebut adalah bahwa Pemilik Indikasi Geografis antara lain harus memiliki Sistem manajemen yang kuat dan efektif, Kualitas produk yang prima dan terjaga konsistensinya dengan baik, Sistem pemasaran termasuk promosi yang kuat, Mampu memasok kebutuhan pasar dalam jumlah cukup secara berkelanjutan, dan Kemauan menegakkan ketentuan hukum terkait Indikasi Geografis.

Semua aspek Indikasi Geografis yang telah diuraikan diatas tersebut sangat membantu sebagai tolok ukur yang digunakan dalam penelitian dan mendorong mengapa diperlukannya upaya pelindungan hukum terhadap suatu produk yang berpotensi sebagai Indikasi Geografis di Indonesia. Perlindungan hukum terhadap Indikasi Geografis memiliki dua karakter kepemilikan yakni kepemilikan yang komunal dan kolektif. Karakter kepemilikan yang komunal artinya menjadi milik bersama masyarakat yang mencakup dalam wilayah Indikasi Geografis terdaftar. ${ }^{10}$ Setelah mendaftarkan produk yang memiliki potensi Indikasi Geografis dan memperoleh perlindungan hukum melalui Indikasi Geografis, masyarakat tersebut

9 Miranda Risang Ayu, 2006, Memperbincangkan Hak Kekayaan Intelektual Indikasi Geografis, Alumni, Bandung, h. 42.

${ }^{10}$ Djulaeka, op.cit, h. 82. 
memiliki hak eksklusif untuk mengedarkan dan memperdagangkan produknya sehingga masyarakat daerah lain dilarang untuk menggunakannya pada produk mereka. Hak eksklusif yang diberikan merupakan reward yang sesuai bagi para pencipta Kekayaan Intelektual. ${ }^{11}$ Berdasarkan analisis bahwa syarat Objektif sebagaimana yang telah diuraikan diatas adalah merupakan unsurunsur yang akan menandakan reputasi, kualitas, dan karateristik yang harus ditunjukkan melalui sebuah produk berpotensi Indikasi Geografis. Unsur-unsur tersebut diteliti dengan tujuan untuk proses perolehan perlindungan hukum Indikasi Geografis.

Syarat subjektif merupakan syarat yang menerangkan siapa saja yang dapat mendaftarkan perlindungan hukum terhadap Indikasi Geografis agar produk tersebut tidak diakui oleh pihak lain, maka Pasal 53 ayat (1), (2), (3) dan (4) Undang-Undang Merek dan Indikasi Geografis tegas menjelaskan pada bunyinya bahwa untuk memperoleh perlindungan hukum sebagai suatu Indikasi Geografis haruslah didaftarkan dengan mengajukan permohonan kepada Menteri sebagaimana dimaksud pada Pasal 53 Undang-Undang Merek dan Indikasi Geografis yang mengatur pihak yang dapat mendaftarkan Indikasi Geografis dan menjadi syarat subjektif. Adapun pihak yang dapat mengajukan pendaftaran ialah Lembaga yang mewakili masyarakat di kawasan geografis tertentu yakni:

1. Pihak yang mengusahakan barang yang merupakan hasil alam atau kekayaan alam, seperti Produsen barang hasil pertanian, Pembuat barang-barang kerajinan tangan atau hasil industri, atau Pedagang yang menjual barang tersebut, Lembaga yang

11 Tomi Suryo Utomo, Hak Kekayaan Intelektual (HKI) di Era Global Sebuah Kajian Komtemporer, Graha Ilmu, Yogyakarta, h. 2. 
diberi kewenangan untuk itu atau Kelompok konsumen barang tertentu; dan

2. Pemerintah Daerah Provinsi atau Kabupaten/Kota

Berdasarkan pasal tersebut diatas, suatu Indikasi Geografis dapat dikatakan telah memperoleh perlindungan apabila Indikasi Geografis tersebut sudah didaftarkan atas permohonan dari lembaga atau komunitas yang merupakan perwakilan dari suatu kelompok masyarakat pada suatu daerah yang memproduksi produk yang bersangkutan

\subsubsection{Mekanisme Pendaftaran Suatu Produk yang Berpotensi Sebagai Indikasi Geografis}

Saat pertama kali Indikasi Geografis mulai berkembang di Indonesia yaitu pada tahun 2001 sampai saat ini, Ditjen KI mendata sudah sekitar 35 produk Indikasi Geografis yang didaftarkan oleh perwakilan dari masing-masing daerah untuk dilindungi di Indonesia. Article 22 TRIPs menyatakan bahwa Indikasi Geografis yang dimaksud dalam TRIPs ini adalah isyarat yang mengidentifikasi suatu identitas produk yang daerah asalnya dari wilayah negara anggota dimana terdapat karakteristik yang menerangkan asal geografis tersebut. 12

Mekanisme pendaftaran suatu produk yang berpotensi sebagai Indikasi Geografis yang diatur didalam Undang-Undang Merek dan Indikasi Geografis serta diatur di dalam Buku Indikasi Geografis Indonesia yang dikeluarkan oleh Direktorat Jenderal Kekayaan

12 Rahmi Jened, 2015 Hukum Merek (Trademark Law) Dalam Era Globalisasi \& Integrasi Ekonomi, Prenadamedia Group, Jakarta, h. 30. 
Intelektual. Adapun tata cara pengajuan permohonan pendaftaran Indikasi Geografis adalah :

1. Permohonan pendaftaran diajukan secara tertulis dalam bahasa Indonesia oleh Pemohon atau melalui Kuasanya dengan mengisi formulir dalam rangkap 3 (tiga) kepada Direktorat Jenderal Kekayaan Intelektual.

2. Pemohon sebagaimana dimaksud harus mencantumkan persyaratan administrasi sebagai berikut:

1) Tanggal, bulan dan tahun;

2) Nama lengkap, kewarganegaraan, dan alamat Pemohon;

3) Nama lengkap dan alamat Kuasa, apabila Permohonan diajukan melalui Kuasa.

3. Permohonan sebagaimana yang dimaksud pada point a harus dilampiri:

1) Surat kuasa khusus, apabila permohonan melalui kuasa;

2) Bukti pembayaran biaya pendaftaran dan pemeriksaan substantif kepada Kantor Kas Negara;

4. Permohonan sebagaimana dimaksud pada point a harus dilengkapi dengan Buku Persyaratan.

5. Permohonan dapat diajukan kepada Direktorat Jenderal Kekayaan Intelektual:

1) Dengan alamat : Direktorat Jenderal Kekayaan Intelektual, Kementrian Hukum dan Hak Asasi Manusia Republik Indonesia J1. H.R. Rasuna Said Kav.8-9, Kuningan, Jakarta Selatan 12190, atau

2) Melalui Kantor Wilayah Kementrian Hukum dan Hak Asasi Manusia Republik Indonesia yang ada di seluruh provinsi Indonesia, atau 
3) Melalui Kuasa Hukum Konsultan Kekayaan Intelektual yang terdaftar.

6. Permohonan diajukan dengan menggunakan formulir permohonan resmi Indikasi Geografis dari Direktorat Jenderal Kekayaan Intelektual.

Adapun Buku Persyaratan yang dimaksud harus dilengkapi dalam pendaftaran Indikasi Geografis mencantumkan beberapa hal berikut :

1. Nama Indikasi Geografis yang dimohonkan pendaftarannya

2. Nama barang yang dilindungi oleh Indikasi Geografis

3. Uraian mengenai karateristik dan kualitas yang membedakan barang yang bersangkutan dengan barang lain yang memiliki kategori sama, dan menjelaskan tentang hubungannya dengan daerah asal barang tersebut

4. Uraian mengenai lingkungan geografis serta faktor alam dan faktor manusia yang merupakan satu kesatuan dalam memberikan pengaruh terhadap kualitas atau karateristik dari barang yang dihasilkan

5. Uraian batas-batas daerah dan/atau peta wilayah yang dicakup oleh Indikasi Geografis dan harus mendapatkan rekomendasi dari instansi yang berwenang

6. Uraian mengenai sejarah dan tradisi yang berhubungan dengan pemakaian Indikasi Geografis untuk menandai barang yang dihasilkan daerah tersebut, termasuk pengakuan dari masyarakat mengenai Indikasi Geografis tersebut.

7. Uraian yang menjelaskan mengenai proses produksi, proses pengolahan dan proses pembuatan yang digunakan sehingga 
memungkinkan setiap pembudidaya di daerah tersebut untuk memproduksi, mengolah atau membuat barang tersebut

8. Uraian megenai metode yang digunakan untuk menguji kualitas barang yang dihasilkan

9. Label yang digunakan pada barang dan memuat Indikasi Geografis

Setelah itu, berkas permohonan pendaftaran Indikasi Geografis yang diajukan kepada Direktorat Jenderal Kekayaan Intelektual akan diperiksa secara administratif dan substantif paling lama dalam waktu 14 hari. Apabila memenuhi persyaratan, maka Direktorat Jenderal Kekayaan Intelektual memberikan tanggal penerimaan Permohonan Pendaftaran. Apabila permohonan pendaftaran telah memenuhi persyaratan, dalam jangka waktu paling lama 1 (satu) bulan Direktorat Jenderal Kekayaan Intelektual meneruskan permohonan pendaftaran kepada Tim Ahli Indikasi Geografis dan dalam jangka waktu paling lama 2 (dua) tahun sejak menerima permohonan pendaftaran dari Direktorat Jenderal Kekayaan Intelektual, Tim Ahli Indikasi Geografis melakukan pemeriksaan substantif, apabila terpenuhi, selanjutnya didaftarkan dalam Daftar Umum Indikasi Geografis.

Berdasarkan usulan tersebut, Direktorat Jenderal Kekayaan Intelektual dalam jangka waktu paling lama 30 (tiga puluh) hari akan mengumumkan informasi terkait dalam Berita Resmi Indikasi Geografis selama 3 (tiga) bulan. Setelah itu masa pengumuman selesai, Direktorat Jenderal Kekayaan Intelektual akan menerbitkan sertifikat Indikasi Geografis. Jangka waktu perlindungan pada Indikasi Geografis terdaftar mendapat perlindungan hukum yang berlangsung selama ciri dan/atau kualitas masih bertahan yang 
menjadi dasar dalam pemberian perlindungan hukum Indikasi Geografis. Dengan kata lain bahwa Indikasi Geografis dilindungi selama terjaganya reputasi, kualitas, dan karakteristik yang menjadi dasar diberikannya pelindungan Indikasi Geografis pada suatu barang, diatur dalam Undang-Undang Merek dan Indikasi Geografis dalam Pasal 61.

Langkah selanjutnya setelah pendaftaran indikasi geografis ialah pengumuman. Tujuan pengumuman permohonan Indikasi Geografis adalah sebagai informasi dan/atau tanda sahnya kepemilikan atas suatu produk dan menghindari agar pihak lain tidak dapat merebut hak kepemilikan tersebut serta kedepannya pemilik Indikasi Geografis yang sudah terdaftar tersebut dapat memberikan keberatan atau sanggahan atas pendaftaran Indikasi Geografis yang sama apabila ada. Pendaftaran diterima, maka perlindungan Indikasi Geografis diberikan selama ciri dan/atau kualitas Indikasi Geografis tersebut masih ada dan sesuai dengan persyaratan saat diajukan pendaftarannya.

Adapun pendaftaran Indikasi Geografis tidak dapat dilakukan secara eksplisit tertuang dalam Pasal 56 ayat (1) huruf a sampai huruf c Undang Undang Nomor 20 tahun 2016 tentang Merek dan Indikasi Geografis yaitu permohonan Indikasi Geografis yang tidak dapat didaftar jika :

1. Bertentangan dengan ideologi negara, peraturan perundangundangan, moralitas, agama, kesusilaan dan ketertiban umum.

2. Menyesatkan atau memperdaya masyarakat mengenai reputasi, kualitas, karakteristik, asal sumber, proses pembuatan barang, dan/atau kegunaannya; dan 
3. Merupakan nama yang telah digunakan sebagai varietas tanaman dan digunakan bagi varietas tanaman yang sejenis, kecuali ada penambahan padanan kata yang menunjukkan faktor Indikasi Geografis yang sejenis.

Berdasarkan analisis menunjukkan bahwa pada umumnya mekanisme pendaftaran mengandung syarat tertentu, ada syarat yang harus dipenuhi dan ada syarat yang harus dihindari. Demikian pula dengan mekanisme pendafataran Indikasi Geografis, ditentukan syarat untuk objek yang tidak dapat didaftarkan. Adapun tujuan syarat tersebut adalah untuk menghindari terjadinya sengketa dikemudian hari atas sebuah objek Indikasi Geografis. Dalam pasal diatas disebutkan bahwa permohonan Indikasi Geografis akan ditolak apabila "menyesatkan atau memperdaya masyarakat mengenai reputasi, kualitas, karakteristik, asal sumber, proses pembuatan barang, dan/atau kegunaannya", dapat diartikan bahwa yang disebut dengan kategori menyesatkan masyarakat disini adalah apabila dalam keadaan tertentu masyarakat dapat tertipu atas informasi yang melekat pada nama suatu indikasi tersebut. Dengan kata lain apabila suatu Indikasi Georagrafis tersebut tidak sesuai dengan kenyataannya maka akan ditolak pendaftarannya agar tidak ada pihak yang nantinya merasa tertipu dengan produk tersebut. Jadi untuk melakukan pendaftaran produk yang berpotensi sebagai Indikasi Geografis memang perlu melewati banyak tahapan-tahapan serta syarat-syarat yang harus dipenuhi terlebih dahulu.

\section{PENUTUP}

\subsection{Kesimpulan}


Berdasarkan pembahasan yang telah disampaikan diatas, maka terdapat dua kesimpulan yaitu :

1. Kriteria agar suatu produk dapat didaftarkan sebagai Indikasi Geografis adalah perlu memenuhi syarat objektif dan syarat subjektif. Selain tanda pembeda, aspek-aspek khusus dari nama asal barang juga harus memiliki nilai ekonomis. Artinya bahwa nama asal itu tidak hanya berfungsi sebagai pembeda antara barang satu dan lainnya, tetapi juga harus jelas bahwa tempat asal ini memiliki pengaruh yang besar terhadap peningkatan kualitas atau mutu barang tersebut.

2. Mekanisme pendaftaran suatu produk yang berpotensi sebagai indikasi geografis yaitu diawali dengan pengajuan permohonan kepada Direktorat Jendral Hak Kekayaan Intelektual, lalu Tim Ahli Indikasi Geografis melakukan pemeriksaan substantif, setelah itu diterbitkannya sertifikat Indikasi Geografis. Apabila suatu Indikasi Georagrafis tidak sesuai dengan kriteria pendaftaran maka akan ditolak agar tidak ada pihak yang nantinya merasa tertipu dengan produk tersebut mengingat suatu Indikasi Geografis yang terdaftar berarti memiliki kualitas dan mutu yang baik yang menjadikan suatu produk bisa memiliki nilai ekonomis yang lebih tinggi.

\subsection{Saran}

Adapun saran yang dapat diberikan berdasarkan permasalahan diatas adalah :

1. Masyarakat diharapkan membantu pemerintah melindungi Kekayaan Intelektual dengan cara segera mendaftarkan produkproduk yang berpotensi tersebut melalui Indikasi Geografis 
dengan memperhatikan kriteria-kriteria yang ada sebelum melakukan pendaftaran.

2. Masyarakat hendaknya menggali potensi-potensi Indikasi Geografis yang tertanam di Indonesia lalu mendaftarakannya dengan mekanisme yang berlaku sesuai peraturan perundangundangan. Namun, dalam membuat mekanisme pendaftaran Indikasi Geografis, pemerintah harus memperjelas hal-hal apa saja yang tidak boleh didaftarkan agar tidak menimbulkan salah penafsiran oleh masyarakat.

\section{DAFTAR PUSTAKA}

\section{Buku}

Atsar, Abdul, 2018, Mengenal Lebih Dekat Hukum Hak Kekayaan Intelektual, Deepublish, Yogyakarta.

Amiruddin, Zainal Asikin, 2016, Pengantar Metode Penelitian Hukum, Rajagrafindo Persada, Jakarta.

Djulaeka, 2014, Konsep Perlindungan Hak Kekayaan Intelektual Perspektif Kajian Filosofis HaKi Kolektif-Komunal, Setara Press, Malang.

Risang Ayu, Miranda, 2006, Memperbincangkan Hak Kekayaan Intelektual Indikasi Geografis, Alumni, Bandung.

Supasti Dharmawan, Ni Ketut, dkk, 2018, Harmonisasi Hukum Kekayaan Intelektual Indonesia, Swasta Nulus, Denpasar.

Jened, Rahmi, 2015, Hukum Merek (Trademark Law) Dalam Era Global dan Integrasi Ekonomi, Prenamedia Group, Jakarta.

Utomo, Tomi Suryo, 2010, Hak Kekayaan Intelektual (HKI) di Era Global Sebuah Kajian Kontemporer, Graha Ilmu, Yogyakarta.

\section{Jurnal Ilmiah}


Yesinungrum, Winda Risna, 2015, "Perlindungan Hukum Indikasi Geografis Sebagai Bagian Dari Hak Kekayaan Intelektual", Jurnal IUS, Vol. III, No. 7.

URL:http://jurnalius.ac.id/ojs/index.php/jurnalIUS/article/vie w/198 diakses pada tanggal 4 Februari 2019 pukul 22:17.

Haris, Wiranata dan Sri Indrawati, Anak Agung, 2014, "Pendaftaran Kembali Hak Merek Dagang Indikasi Geografis", Jurnal Kertha Semaya, Fakultas Hukum Universitas Udayana, Vol. II, No. 5, URL:

https://ojs.unud.ac.id/index.php/kerthasemaya/article/view/1 0357, diakses pada tanggal 19 Februari 2019 pukul 16:35.

\section{Peraturan Perundang-Undangan}

Undang-Undang Nomor 20 Tahun 2016 tentang Merek dan Indikasi Geografis

Peraturan Pemerintah Republik Indonesia Nomor 51 Tahun 2007 tentang Indikasi Geografis 